\title{
4. МАЙСТЕР-КЛАС
}

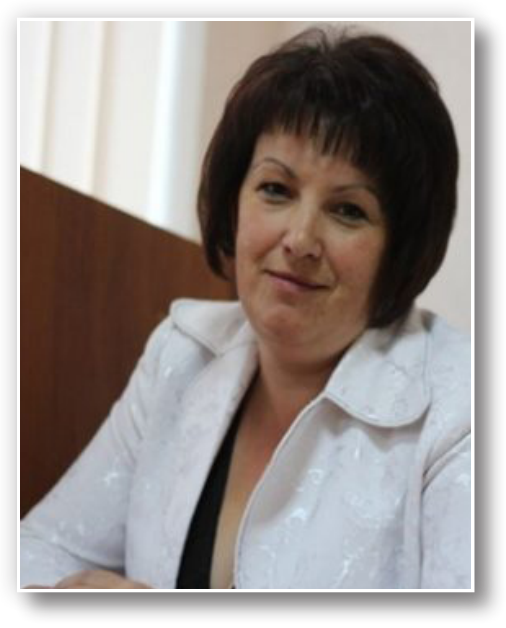

Марія Іванівна Замелюк, кандидат педагогічних наук, старший викладач кафедри теорії та методики дошкільної освіти КЗВО «Луцький педагогічний коледж», м. Луцьк, Україна

iD https://orcid.org/0000-0001-6352-7908

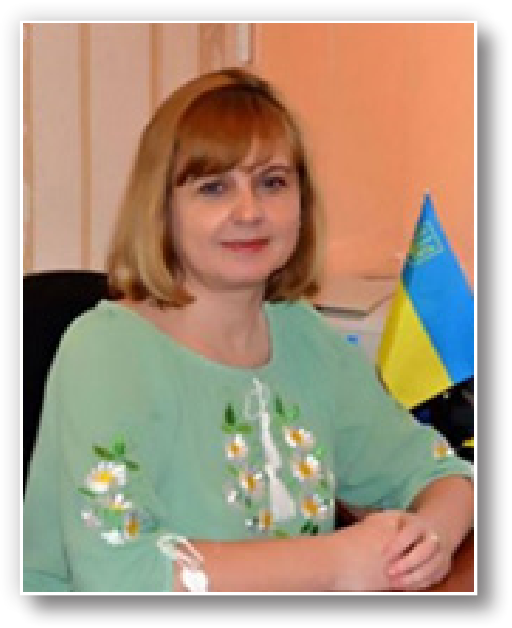

Алла Петрівна Хомярчук, викладач кафедри КЗВО «Луцький педагогічний коледж», м. Луцьк, Україна

УДК 373.2: 37 :74.01

DOI $h$ ttps://doi.org/10.32405/2309-3935-2021-4(83)-66-69

\section{ІНТЕРВЕНЦІЯ ПЕДАГОГІКИ ПАРТНЕРСТВА ЗАСОБАМИ КРЕАТИВНОЇ СТУДІЇ «МАЙСТЕРНЯ ЛЯЛЬОК»}

Анотація.

У статті представлено розробку креативної студї «Майстерня ляльок». Запропоновано методику лялькотерапї на відновлення иілісності та внутрішньої рівноваги учасників за допомогою творчого самовираження. У студї можливо власноруч створювати характерні та казкові образи ляльок, опановуючи в процесі різноманітні види творчої діяльності, а також отримуючи нові знання про малюнок, живопис і скульптуру.

Ключові слова: лялькотерапія; творчий розвиток особистості; педагогіка партнерства.

Креативна студія «Майстерня ляльок» має свій чіткий і складний профіль і надає розвитку різним ремеслам, процесам дизайну, історії, методам роботи тощо. Тут можна простежити інтервенцію педагогіки партнерства в комунікації: неоднозначність і «опалізація» (двостороння поява), метафора і перехідні явища, синергія, абстракція та стилізація, перехресне естетичне вираження тощо. Баченням може бути те, що дитина за допомогою естетичних процесів навчання стає спроможною трансформувати деякі складні, суперечливі й уривчасті враження від сучасної культури в динамічні сили. Тому процес кожного творця у креативній студії оживає завдяки його вибору тканин, ескізів, простих візе- рунків і варіацій для досконалого створення ляльки.

Партнерство, що грунтується на взаємодії між учнем, учителем і батьками, спільний процес пізнання і відкриття, постійне створення ситуації успіху - це складові самореалізації учня в освітньому середовищі.

\section{Mema cmydiï:}

- ознайомити учасників з процесом виготовлення ляльки; вчити виготовляти свою ляльку;

- розвивати уяву, фантазію та творчі здібності учасників; черпати інформацію 3 книжок, журналів, Інтернету;

- розвивати спостережливість, творчу уяву, моторику рук, логічне та образне мислення, пам'ять, увагу через практичну роботу; 
- прививати любов до мистецтва;

- виховувати толерантне ставлення один до одного, взаємну співпрацю;

- виховувати посидючість, охайність, свободу творчого рішення, вміння закінчувати свою роботу.

Oрганізація: програма творчої майстерні передбачає проведення однієї групової зустрічі в тиждень.

Обладнання: матеріал для виконання ляльки (шматочки тканини, нитки, тасьма).

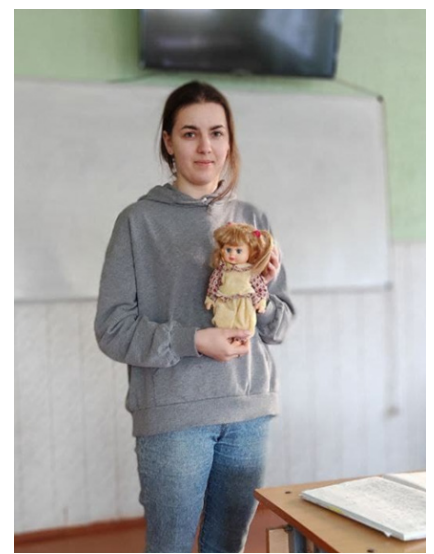

Фото 1, 2. Знайомство «Улюблена лялька мого дитинства»

Тема заняття 2: Казкові і життсві персонажі. Мій образ.

План заняття

1. «Мій образ» - індивідуальний вибір способу.

2. Розробка власного образу.

3. Робота над ескізами (мімічні характеристики, зовнішній вигляд персонажа, акценти, що підкреслюють характерність персонажа).

4. Послання художника майбутнім авторам «Характер - композиція - пропорції ляльки».

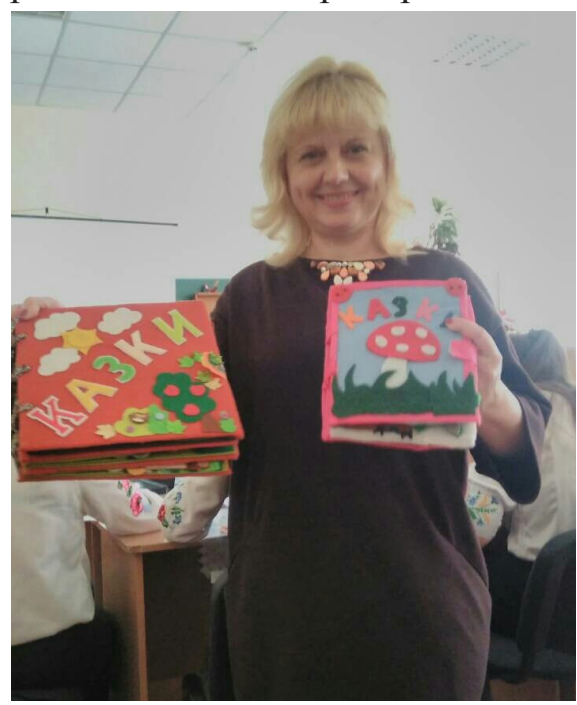

Фото 3. Розгляд казкових персонажів

Тема заняття 3: Пластичний ескіз образу План заняття

1. Освоєння досвіду творення пластичного ескізу ляльки.

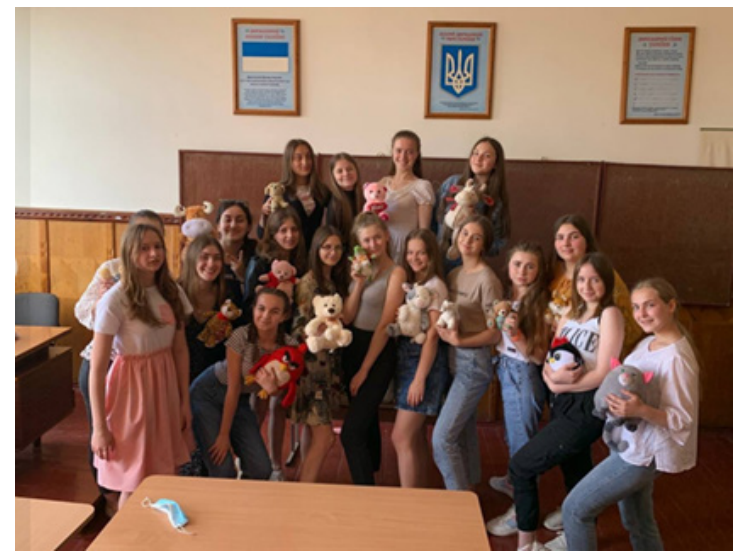

\section{Структура програми}

Тема заняття 1: Креативна студія

План заняття

1. Знайомство «Улюблена лялька мого дитинства».

2. «Майстерня ляльок».

3. Обговорення та прийняття правил спільної діяльності в групі.

4. Освоєння елементарних навичок сценічної майстерності з лялькою.

2. Послання художника-лялькаря майбутнім авторам «Таємниці майстерності театральної ляльки».

3. Групове доопрацювання способу (мозковий штурм).

4. Обговорення результатів творчого процесу.

Тема заняття 4: Портрет об’смного персонажа План заняття

1. Технологічні основи вирізання голови.

2. Посилення виразності характеру; образу 3 допомогою рук і ніг персонажа.

Тема заняття 5: Колористика образу

План заняття

1. Про поєднання кольорів.

2. Освоєння досвіду розпису об'ємних складових лялькового образу.

3. Послання художника-лялькаря початківцям авторам «Таємниці розпису ляльки-артиста».

Тема заняття 6: Збагачення образу за рахунок театрального костюма

План заняття

1. Особливості пропорцій ляльки.

2. Силует ляльки.

3. Принципи крою костюма ляльки.

4. Костюм - доповнення образу. Пошук костюма персонажа, що підкреслює його приналежність до певної касти, історичної епохи.

Тема заняття 7: Додаткова атрибутика лялькового персонажа

План заняття

1. Технологія з'єднання складових ляльки.

2. Підбір та виготовлення додаткових елементів, що підкреслюють характерні особливості персонажа. 
3. Завершення образу за рахунок використання додаткової атрибутики: прикраси, відмінна символіка.

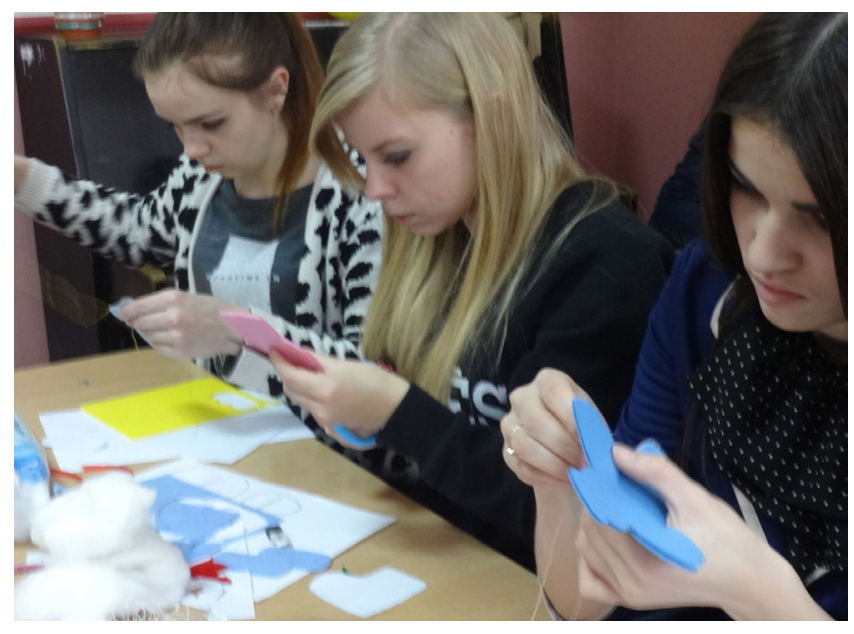

Фото 4. Творчий процес - пошиття ляльки
Тема заняття 8: Презентація ляльки. Нові сценарії.

План заняття

1. Урочиста презентація нової ляльки, фотосесія.

2. Групове обговорення характерних особливостей ляльки.

3. Розробка нових казкових сценаріїв, в яких може брати участь виконана лялька.

Підсумкове заняття.

Створення ляльки - акт творчого самовираження, тому завершення роботи над лялькою завжди свято для автора. У «Майстерні ляльок» ритуал завершення - це презентація з фотосесією нової ляльки і лялькаря. Працюючи 3 лялькою, особистість «з'єднується» 3 образом, «передає» йому свої почуття, відкриває в собі приховані ресурси, може вільно транслювати оточуючим свої потреби. Саме в цьому дивовижному перевтіленні педагогічного партнерства полягає основний принцип лялькотерапії.

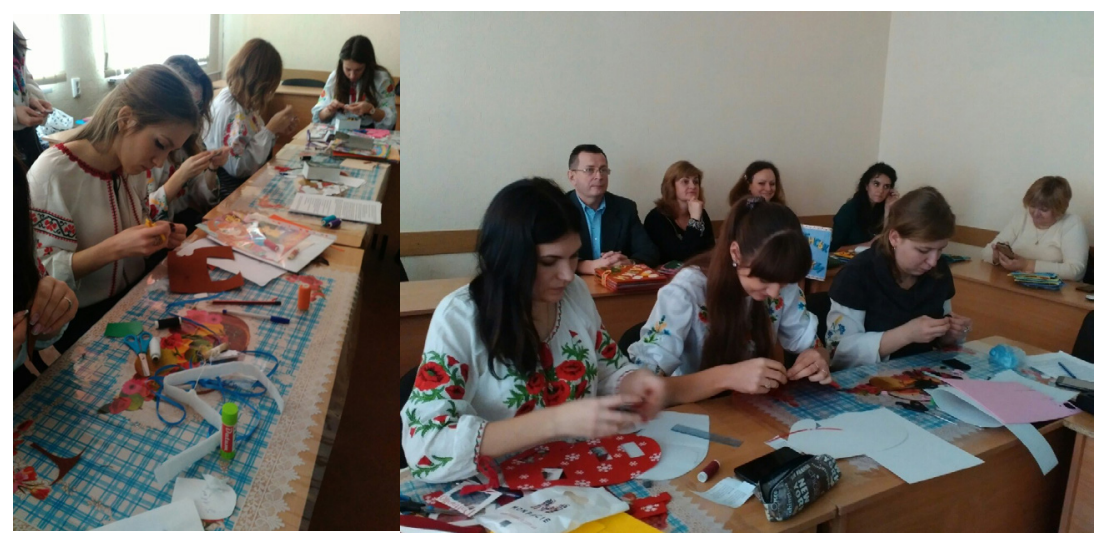

Фото 5, 6. Робота студентів над завершенням образу виготовлення додаткових елементів для ляльки
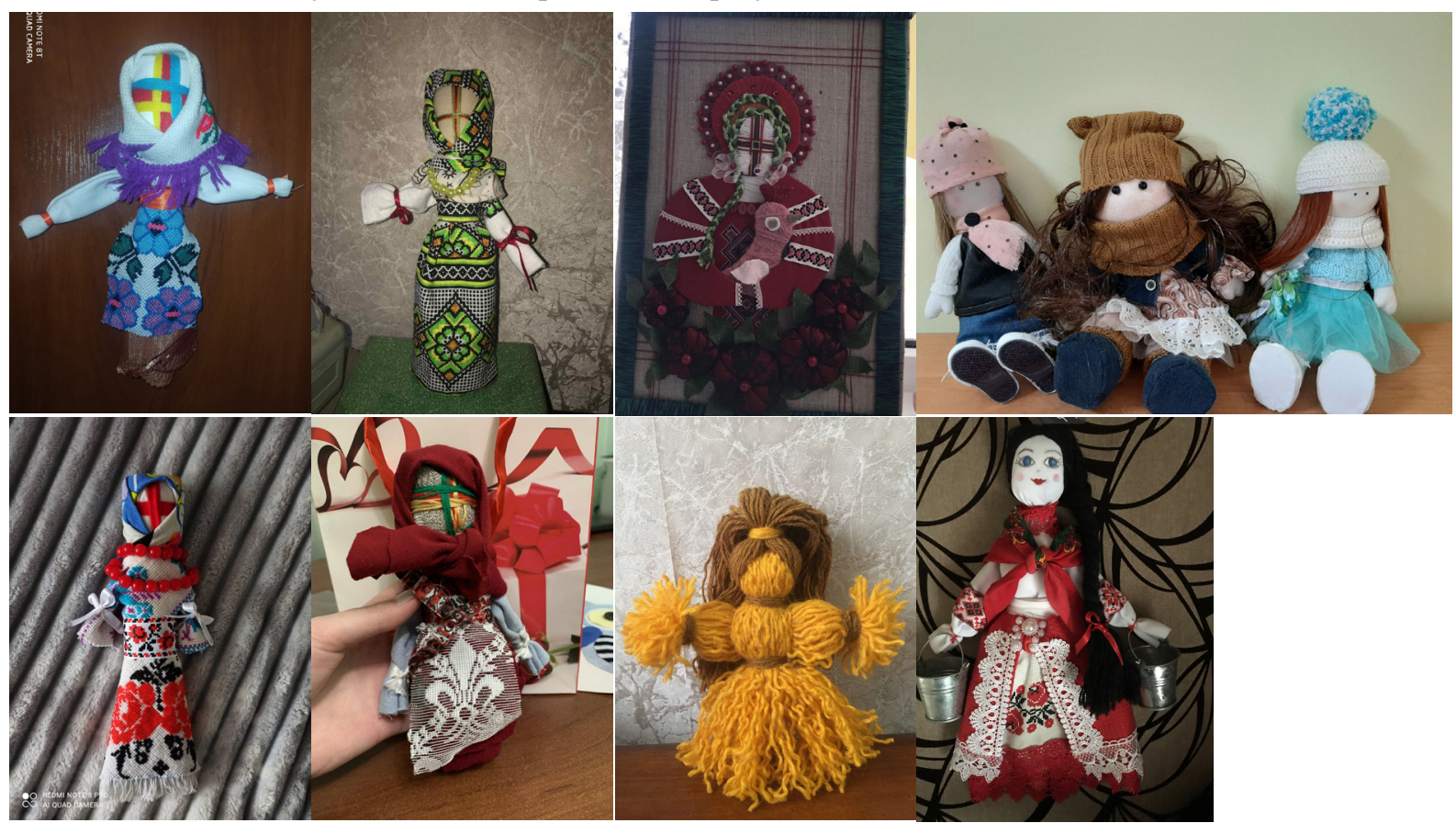

Підбірка фото. Роботи студентів спеціальності 013 «Початкова освіта» 
Таким чином, педагогіка партнерства є важливим чинником ефективної взаємодії учасників освітнього процесу за умов Нової української школи, головною метою якої є підтримка учнів, що сприяє розвитку їхніх можливостей, задовольняє інтелектуальні, емоційні та соціальні потреби дітей, що відповідає запитам сучасної освітньої теорії та практики.

Отже, партнерство і так звані комунікації «творимо майбутне разом» надихають на пошук нових форм співпраці та залучення батьків до освітнього процесу. Дуже цікавим для батьківської громадськості є участь у майстер-клаcax, як точка дотику, шлях співпраці, взаєморозуміння системі «батьки - вчителі - учні».

\section{Використані літературні джерела}

1. Замелюк M. I. Арт-терапія як засіб творчої самореалізації особистості / М. І. Замелюк, Л. І. Магдисюк, Н. В. Ольхова // Психологія: реальність і перспективи : збірник наукових праць Рівненського державного гуманітарного університету / упоряд.: Р. В. Павелків, Н. В. Корчакова. - 2018. - Вип. 10. - С. 50-57.

2. Інновації у роботі вчителя початкових класів: виклики і реалії НУШ: матеріали Всеукр. наук.практ. конф. (Львів, 14 квіт. 2020 р.). - Львів : Генезум, 2020. $-203 \mathrm{c}$.

3. Лебедєва Л. Д. Практика арт-терапії: підходи, діагностика, система занять / Л. Д. Лебедєва. СПб. : Мова, 2005. - 256 с.

4. Микитенко Л. С. Партнерство вчителів та батьків на шляху формування в учнів готовності до самореалізації / Л. С. Микитенко // Матеріали XI Міжнар. фестивалю педагогічних інновацій / [Упор. Назаренко Г. А.]. У двох томах. Т. 2. - Черкаси : КНЗ «ЧОІПОПП ЧОР», 2019. - С. 108-110.

\section{References}

1. Zameliuk, M. I., Mahdysiuk, L. I., \& Olkhova, N. V. (2018). Art-terapiia yak zasib tvorchoi samorealizatsii osobystosti [Art therapy as a means of creative self-realization of personality]. Psykholohiia: realnist $i$ perspektyvy - Psychology: reality and prospects. Vol. 10. P. 50-57. [in Ukrainian].

2. Innovatsii u roboti vchytelia pochatkovykh klasiv: vyklyky i realii NUSh [Innovations in the work of primary school teachers: challenges and realities of NUS] (2020). All-Ukrainian. scientific-practical conf. Lviv, 203 p. [in Ukrainian].

3. Lebedieva, L. D. (2005). Praktyka art-terapii: pidkhody, diahnostyka, systema zaniat [Practice of art therapy: approaches, diagnostics, system of classes]. St.Peterburg, 256 p. [in Ukrainian].

4. Mykytenko, L. S. (2019). Partnerstvo vchyteliv ta batkiv na shliakhu formuvannia $\mathrm{v}$ uchniv hotovnosti do samorealizatsii [Partnership of teachers and parents on the way to forming students' readiness for self- realization]. XI International. festival of pedagogical innovations. Cherkasy, P. 108-110. [in Ukrainian].

Zameliuk Mariia, Candidate of Pedagogical Sciences, Senior Lecturer of the Department of Theory and Methods of Preschool Education, "Lutsk Pedagogical College", Lutsk, Ukraine

Khomiarchuk Alla, Lecturer at the Department of Lutsk Pedagogical College, Lutsk, Ukraine

\section{INTERVENTION OF PEDAGOGY OF PARTNERSHIP BY MEANS OF CREATIVE STUDIOS "PUPPET WORKSHOP"}

Summary.

In the article presented by the developer of the creative studio "Doll Workshop". The method of puppet therapy to restore the integrity and internal balance of participants through creative selfexpression is proposed. In the studios it is possible to create your own characteristic and fabulous images of dolls, mastering various types of creative activities in the process, gaining knowledge about drawing, painting and sculpture. The pedagogy of partnership is the best factor of effective interaction of participants in the educational process in the New Ukrainian school, the main support of students, which promotes their development, meeting the intellectual, emotional and social needs of children, responsible for modern educational theory and practice. In the process of pedagogy of partnership, the vector of activity is aimed at the student's self-knowledge, the process of interaction with the world and modern activities.

Everyday care for parents, parents, friends, neighbors, educators should be the main direction of organizing children's lives. The description of what for others has a fruitful effect on the personality, as it generates the best and freshest traits - selflessness, energy, the pump of their own ability and insecurity for other people, protection, good than opportunity. There is a balance in a child's life between what he offers and what he moves away from. The main task of partnership pedagogy is to overcome the inertia of thinking, the transition to a qualitatively new level of building relationships between participants in the educational process. This task is realized in the joint activities of teachers and students, teachers and parents, which ensures the relationship, common interests and aspirations to involve personal development of students.

Partnership and so-called communications "Creating the future together" searches for new forms of employees and the involvement of parents in the educational process. It is very interesting for the parent community to participate in master classes as a point of contact, a way of cooperation, mutual understanding of the system "parents-teachers-users".

Keywords: puppet therapy; creative development of personality; pedagogy of partnership. 